\title{
An Antitrust Challenge to the NCAA Transfer Rules
}

\author{
Sarah M. Konsky†
}

The National Collegiate Athletic Association (NCAA) requires transferring student-athletes to complete one full year of "academic residence" at their transfer schools before becoming eligible to play sports for the transfer schools.' The transfer rules apply in their most stringent form to student-athletes in "revenue" sports: men's basketball, football, and ice hockey. Thus, if a college football player were to begin his career at Florida State University and then transfer to the University of Illinois, he would be unable to play for one season and might not be able to receive institutional financial aid. The transfer rules place unique limitations on student-athletes, as college students not participating in athletics can transfer freely from college to college, and professional athletes can transfer freely from team to team. ${ }^{2}$

In this Comment, I argue that the NCAA transfer rules violate Section 1 of the Sherman Act, which makes illegal "every contract, combination in the form of trust or otherwise, or conspiracy, in restraint of trade or commerce among the several States." Part I of this Comment provides history and background information about the NCAA and the transfer rules. Part II then sets out the relevant antitrust law, including the applicability of antitrust law to the NCAA, courts' inconclusive application of antitrust law to the transfer rules, and courts' antitrust analysis of similar regulations in professional sports.

In Part III, I argue that the NCAA transfer rules violate the Sherman Act. The argument is structured as follows: first, the NCAA transfer rules are sufficiently commercial to warrant antitrust scrutiny; second, the rules have a significant anticompetitive effect on the national market for student-athletes' services; and third, the regulations fail an antitrust analysis because (1) any procompetitive rationales that could be offered to justify the rule are insufficient to overcome the anticompetitive effects and (2) less restrictive alternatives could achieve the same procompetitive aims.

$\dagger$ B.S. 2001, University of Illinois at Urbana-Champaign; J.D. Candidate 2004. The University of Chicago.

1 See NCAA Operating Bylaws Art 14.5 et seq, online at http://www.ncaa.org/library/ membership/division_i_manual/2002-03/2002-03_ncaa_d1_manual.pdf (visited Oct 25,2003).

2 See Part II.D.1.

$3 \quad 15$ USC $\$ 1$ (2000). 


\section{HiSTORY OF NCAA REGULATION AND THE TRANSFER RULES}

A. Overview of the NCAA

The modern NCAA is a far cry from the small, safety-oriented organization of the early 1900s. The NCAA was formed in the early $1900 \mathrm{~s}$ in response to the increasing number of injuries and deaths in college sports. ${ }^{4}$ Thus, in its early years, the NCAA aimed to manage externalities by protecting students and loosely organizing sports."

The NCAA has expanded dramatically since. Its voluntary membership has grown to include 1,258 institutions and their 361,175 student-athletes. The number and breadth of NCAA regulations have increased exponentially: The NCAA has come to regulate nearly every aspect of college sports,' from television contracts ${ }^{8}$ to recruiting and eligibility.'

The structure of the NCAA now resembles that of a corporation. Its ruling body, called the NCAA Council, consists of a president, secretary-treasurer, and forty-four institutional representatives who set general policy and oversee the various committees.' A smaller Executive Committee oversees the organizational bureaucracy and ongoing business;" an Infractions Committee hears cases about potential rule violations and levies penalties.'

1. The NCAA's purported goals: education and amateurism.

The NCAA claims that it "strives to maintain intercollegiate athletics as an integral part of the educational program and the athlete as an integral part of the student body." "..3 Indeed, the NCAA requires in-

4 See Kevin E. Broyles, NCAA Regulation of Intercollegiate Athletics: Time for a New Game Plan, 46 Ala L Rev 487, 489 (1995) (discussing the early history of the NCAA). For example, in 1905 there were more than eighteen deaths in intercollegiate football alone. See Rodney K. Smith, A Brief History of the National Collegiate Athletic Association's Role in Regulating Intercollegiate Athletics, 11 Marq Sports L Rev 9, 12 (2000). The combined efforts of the White House and colleges in 1905 led to the creation of a sixty-two-member Intercollegiate Athletic Association, renamed the National Collegiate Athletic Association in 1910. Id.

5 See Broyles, 46 Ala L Rev at 490-91 (cited in note 4).

6 See Composition of the NCAA (Mar 4, 2003), online at http://wwwl.ncaa.org/ membership/membership_svcs/membership_breakdown.html (visited May 18, 2003).

7 See generally Smith, 11 Marq Sports L Rev at 12-22 (cited in note 4). The NCAA rules manual grew from 161 pages in 1970-71 to three volumes totaling over 1,000 pages in 1998-99. See Andrew Zimbalist, Unpaid Professionals: Commercialism and Conflict in Big-Time College Sports 4-5 (Princeton 1999).

8 See Jack Falla, NCAA: The Voice of College Sports 103-23 (NCAA 1981).

9 See id at 139-56.

10 See Broyles, 46 Ala L Rev at 493 (cited in note 4).

11 See Murray Sperber, College Sports Inc.: The Athletic Department vs The University 309 (Henry Holt 1990).

12 See Zimbalist, Unpaid Professionals at 174 (cited in note 7).

13 The Purposes of the NCAA, online at http://www.ncaa.org/about/purposes.html (visited 
coming student-athletes to have minimum scores on college entrance exams and to have satisfactorily completed standard core high school courses. ${ }^{14}$ Once in college, the student-athletes must maintain a certain grade point average and enroll in a certain number of credit hours to remain eligible for competition."

However, commentators and journalists question the centrality of these "academic goals." Rigorous athletic practice and competition schedules often force student-athletes to do just enough academically to remain eligible for athletic competition. ${ }^{17}$ Top athletic programs struggle to graduate student-athletes. For example, only nine of the sixty-five men's basketball teams in the 2002 NCAA tournament had graduation rates higher than those of male students generally at their respective institutions; statistics are similar for men's football teams in the Bowl Championship Series. ${ }^{18}$ Further, special treatment for student-athletes - from special living conditions to curricula - reinforce a "class system" in which student-athletes are set apart from the rest of the student body." As the late Bear Bryant said, "At the level we play, the boy is really an athlete first and a student second."

The NCAA also holds out amateurism as a central goal of the organization. ${ }^{2 !}$ The organization developed principles of amateurism

May 18, 2003).

14 See Zimbalist, Unpaid Professionals at 32-33 (cited in note 7).

15 See NCAA Operating Bylaws Art 14.01.2 (cited in note 1).

16 See, for example, Christopher L. Chin, Comment, Illegal Procedures: The NCAA's Unlawful Restraint of the Student-Athlete, 26 Loyola L Rev 1213, 1234 (1993) ("[T]he NCAA's academic goals are fallacious because neither the NCAA nor the student-athlete pursues them."). See generally Rick Telander, Something Must Be Done, Sports Illustrated 92 (Oct 2, 1989) (asserting that "the nation's universities are shamelessly exploiting the players and debasing themselves by perpetuating the myth of the 'amateur' student-athlete").

17 Melvin L. Braziel, United We Stand: Organizing Student-Athletes for Educational Reform, 4 Sports Law J 81, 85 (1997) (noting that practice schedules and year-round preparation constrain educational achievement).

18 See Welch Suggs, Athletes' Graduation Rates Hit All-Time High, Chron Higher Educ 47 (Oct 4, 2002); Steve Weiberg, BCS Schools Don't Measure Up, USA Today 3C (Oct 18, 2002). The NCAA reports that 58 percent of students generally graduate, compared with 36 percent of male basketball players and 52 percent of male football players. See Phil Mushnick, A Hoopless Situation: NCAA's Poor Grad Rates a' Bad Joke, NY Post 83 (Nov 3, 2002). However, general graduation rates do not adequately reflect the poor performance of student-athletes in top athletic programs. For example, UNLV did not graduate a single male basketball player who arrived between 1988 and 1995; Syracuse did not graduate a black male basketball player who arrived between 1987 and 1995; Louisville and Arkansas did not graduate a black male basketball player who arrived between 1989 and 1995. See Steve Weiberg, Off Court, Top Teams Fall Short, USA Today $1 \mathrm{C}$ (Oct 18, 2002).

19 See Zimbalist, Unpaid Professionals at 12 (cited in note 7).

20 Lee Goldman, Sports and Antitrust: Should College Students Be Paid to Play?, 65 Notre Dame L Rev 206, 242 (1990).

21 The NCAA's 2002-03 Manual indicates that the NCAA's basic purpose is "to maintain intercollegiate athletics as an integral part of the educational program and the athlete as an integral part of the student body and, by so doing, retain a clear line of demarcation between intercollegiate athletics and professional sports." NCAA Manual Art 1.3.1, online at http:// 
shortly after its inception, although the principles lacked an enforcement mechanism until nearly $1950 .{ }^{22}$ Today, many NCAA regulations are intended to preserve amateurism, including a prohibition on paying athletes, a regulation barring athletes from holding a job during the school year, a limit on the size of the maximum grant, and a regulation mandating that athletes cannot retain eligibility once they sign with an agent."

Commentators question the NCAA's purported goal of promoting amateurism, dubbing student-athletes in revenue sports "unpaid professionals" ${ }^{24}$ for the money that their talents net their schools and the NCAA. ${ }^{25}$ For example, a football team participating in one of the four Bowl Championship Series games receives a payout of $\$ 13.5$ million, to be shared with the other teams in the conference. ${ }^{26}$ The NCAA has entered into a $\$ 6$ billion contract with $\mathrm{CBS}$, under which the network will televise the NCAA men's basketball tournament for eleven years. ${ }^{27}$ The high-dollar stakes of college sports make the NCAA a "unique industry" that nevertheless "manages not to pay its principal producers a wage or salary. ${ }^{2 k}$ In revenue sports, amateurism is arguably a relic of the past.

\section{The NCAA as a commercial cartel.}

The NCAA has developed into a major commercial entity. Despite its "nonprofit" status, the organization reports anticipated yearly operating revenues of more than $\$ 422$ million. ${ }^{29}$ In fact, it reports television revenues alone of $\$ 370$ million annually, totaling almost 90 percent of its revenues."

www.ncaa.org/library/membership/division_i_manual/2002-03/A01.pdf (visited May 19, 2003).

22 See Broyles, 46 Ala L Rev at 491-99 (cited in note 4).

23. See Zimbalist, Unpaid Professionals at 18 (cited in note 7).

24 Id at 53. See also Braziel, 4 Sports Law $J$ at 83 (cited in note 17) ("The pulse of amateurism in intercollegiate athletics, especially in men's Division I-A football and Division I basketball, is faint and fading fast.").

25 Arguably, the ideals of amateurism still exist in non-revenue sports. However, the scope of this Comment is limited to student-athletes in revenue sports, since the transfer rules apply in their most stringent form to these students.

26 See Andrew Bagnato, Bowl Bonanza Has Players Seeking Share, Chi Trib 1C (Jan 1, 2003).

27 See Don Walker, NCAA Banks on the Final Four Frenzy, Milwaukee J Sentinel 1A (Mar 30, 2002); Dick Jerardi, College Players Being Ignored While Others Raking in Money, Houston Chron 3 Sports (Oct 15, 2000); Steve Weiberg, A New Ballgame: NCAA Takes Another Shot at Trying to Clean Up Its Tarnished Reputation, USA Today 3C (Apr 27, 2000).

28 Zimbalist, Unpaid Professionals at 6 (cited in note 7).

29 The National Collegiate Athletic Association Proposed Budget for Fiscal Year Ended Altgust 31,2003, online at http://www.ncaa.org/financial/2002-03_budget.pdf (visited May 18, 2003). The revenues are spent on distribution to members (for example, $\$ 195$ million to Division 1 members), championships, programming, and other miscellaneous expenses. See id.

30) Id. 
The move toward commercialization occurred gradually. Like many organizations formed for similar purposes, the NCAA shifted its primary focus from managing externalities to increasing joint profits." The organization thus began to act as a successful cartel, regulating both input (the student-athletes themselves) and output (the number of games played and televised) in college athletics.

The NCAA enforces its regulations by disciplining violators. While individual member schools might have an incentive to gain a competitive advantage by not complying with NCAA regulations, the member schools must stay in good standing within the organization to reap the economic benefits of college sports."

In that sense, the NCAA resembles a typical commercial cartel. Cartel agreements typically restrict price competition and limit production to create above-average profits from outputs and to generate a flow of economic rents from inputs compensated below their market value. ${ }^{39}$ Ultimately, the NCAA maximizes profits beyond a competitive rate and keeps the windfall in the hands of select few administrators, athletic directors, and coaches.

\section{B. The NCAA Transfer Rules}

One way the NCAA regulates college athletics is by limiting the free movement of student-athletes from one college to another. Under the NCAA transfer rules, a student-athlete transferring from one Division I school" to another must "complete one academic year of residence" at the transfer school before becoming eligible to compete in

31 See Arthur A. Fleisher III, Brian L. Goff, and Robert D. Tollison, The National Collegiate Athletic Association: A Study in Cartel Behavior 20-34 (Chicago 1992).

32 See id at 5 (arguing that the NCAA's activities meet the economic definition of cartel behavior). The authors list five factors suggesting the NCAA is a cartel: (1) the open collusion among member schools extends beyond rule standardization; (2) while revenues to member schools have drastically increased, allowable compensation to student-athletes has remained constant; (3) the NCAA has excluded school brand-name and other capital assets from regulation; (4) the value of student-athletes to their schools is large in relation to the marginal value of the education they are given; and (5) illicit payments to student-athletes suggest that rents are trying to find their way into the relevant input. Id at 7-9.

33 See Matthew J. Mitten, Applying Antitrust Law to NCAA Regulations of "Big Time" College Athletics: The Need to Shift from Nostalgic 19th and 20th Century Ideals of Amateurism to the Economic Realities of the 21st Century, 11 Marq Sports L Rev 1, 3 (2000). Commentators note that much of the NCAA's real power lies in its Infractions Committee, the organization's enforcement arm. See Broyles, 46 Ala L Rev at 493 (cited in note 4).

34 See Mitten, 11 Marq Sports L Rev at 3 (cited in note 33).

35 See Fleisher, Goff, and Tollison, A Study in Cartel Behavior at 25 (cited in note 31).

36 See Marc Edelman, Note, Reevaluating Amateurism Standards in Men's College Basketball, 35 U Mich J L Reform 861,871-77 (2002). See also generally Sperber, College Sports Inc. ch 22 (cited in note 11 ).

37 NCAA member schools are broken into Divisions based on the size of their athletic programs. Division I schools are the major programs. 
Division I sports for that school. ${ }^{3 *}$ The transferring student-athlete does not lose one of his four years of athletic eligibility. However, he still must complete the entirety of his eligibility within the five-year eligibility window prescribed by the NCAA. ${ }^{30}$ Practically, then, a student-athlete wishing to use his maximum four years of athletic eligibility can transfer colleges only once.

The transfer rules apply most stringently to student-athletes participating in Division I "revenue sports." The broadest exception to the transfer rules, allowing student-athletes a one-time transfer without penalty, specifically excludes participants in Division I basketball, football, and men's ice hockey." Other exceptions, such as those for discontinued sports, ${ }^{41}$ military service, ${ }^{42}$ or discontinued academic programs, ${ }^{43}$ are quite narrow and unlikely to apply to many students.

The transfer rules have the effect of dissuading student-athletes to whom they apply from transferring schools. ${ }^{44}$ In an unrestricted market, greater player movement would inevitably occur. Players would seek the teams they most highly value; teams would seek the players they most highly value. Free movement within the market would ultimately reflect an optimal matching of players and teams.

The transfer rules, however, artificially deter players and teams from seeking this optimal match. Players must weigh the benefits of transferring schools against the cost of the one-year penalty. In some cases, the cost of the one-year penalty will outweigh the benefits of transferring. The player will not transfer, despite the fact that the transfer would otherwise be the mutually beneficial outcome for the player and the team. Therefore, the transfer rules have an artificial deterrent effect on student-athlete movement.

38 See NCAA Operating Bylaws Art 14.5 et seq (cited in note 1). See also NCAA 2002-03 Transfer Guide \& IV, online at http://www.ncaa.org/library/general/transfer_guide/2002-03/ 2002-03_transfer_guide.pdf (visited Oct 25, 2003).

39) See NCAA Operating Bylaws Art 14.2.1 (cited in note 1) ("A student-athlete shall complete his or her seasons of participation within five calendar years from the beginning of the semester or quarter in which the student-athlete first registered for a minimum full-time program of studies in a collegiate institution.").

40 Id Art 14.5.5.2.10 (discussing the one-time transfer exception).

41 Id Art 14.5.5.2.6.

42 Id Art 14.5.5.2.5.

43 Id Art 14.5.5.2.3.

44 See Broyles, 46 Ala L Rev at 532-33 (cited in note 4) (discussing the effects of and rationales for the transfer rules). See also Mackey $v$ National Football League, 543 F2d 606, 620 ( 8 th Cir 1976) (noting that witnesses on both sides of a suit challenging the NFL transfer penalty agreed that "there would be increased player movement absent the [pqnalty]").

45 See, for example, Dave Reynolds, One Who Didn't Get Away, Peoria J Star E7 (Nov 18, 2002) (discussing the factors that went into one NCAA basketball player's decision whether to transfer schools). The student-athlete discussed in the article ultimately decided to transfer from Bradley University to the University of New Mexico. See Dave Reynolds, Former Brave Enters Pit as Lobo, Peoria J Star D3 (Jan 25, 2003). 
The NCAA's purported rationales for the transfer rules hinge on the organization's academic and amateurism goals. The NCAA has stated that the transfer rules are intended to "provide a better environment for [the student-athlete's] collegiate experience and to establish appropriate standards to govern the manner in which institutions compete with each other both on and off the field." ${ }^{46}$ Additionally, the NCAA has stated in litigation that the purposes of the transfer rules were "(1) to prevent transfers solely for athletic reasons, (2) to avoid exploitation of student-athletes, and (3) to allow transfer students time to adjust to their new environment."

The purported purposes are not without merit. For example, it is possible that frequent transferring could undermine a studentathlete's ability to receive a quality education. Or, a transferring student-athlete might enter his new school at a disadvantage-his peers would already have had ample time to adjust to the school and the athletic program. Nevertheless, the NCAA's justifications for the transfer rules do not stand up to scrutiny. These justifications will be examined in greater detail, and ultimately refuted, in Part III.

\section{ANTITRUST AND THE NCAA}

This Part provides a brief overview of antitrust law as applied to the NCAA. I first set out the antitrust law that pertains to the NCAA, and then discuss the applicability of antitrust law to the NCAA generally, the transfer rules specifically, and similar regulations in professional sports.

\section{A. Summary of Pertinent Antitrust Laws}

Section 1 of the Sherman Act provides in part that "every contract, combination in the form of trust or otherwise, or conspiracy, in restraint of trade or commerce ... is hereby declared to be illegal." Taken literally, the Sherman Act would bar virtually every private contract, as all contracts technically restrain trade. Further, the Supreme Court has recognized that certain products require horizontal restraints on trade if the product is to exist at all." Courts have there-

46 NCAA 2002-03 Transfer Guide at Introduction (cited in note 38).

47 McHale v Cornell University, 620 F Supp 67, 69-70 (ND NY 1985) (holding that the enforcement of transfer rules was not a state action).

$48 \quad 15$ USC \& 1.

49 See Chicago Board of Trade v United States, 246 US 231, 238 (1918) ("Every agreement concerning trade, every regulation of trade, restrains.").

50 See Broadcast Music, Inc v Columbia Broadcasting Systems, Inc, 441 US 1, 20-21 (1979) (finding that music licensing could not exist unless artists agreed to sell their rights at uniform prices). 
fore limited the breadth of Section 1 of the Sherman Act to prohibit only unreasonable restraints of trade."

In analyzing whether a restraint is unreasonable, a court will first define the relevant market affected by the restraint. A market has two components: (1) the relevant product market, as defined by the products or services in competition with each other; and (2) the relevant geographic market, defined by the area in which the sellers could engage in the competition." After defining the relevant market, a court must define the contours of the alleged restraint at issue in the case.

Finally, a court must determine whether the alleged restraint is illegal under the Sherman Act. Courts recognize a shrinking category of agreements in restraint of trade or commerce, such as price-fixing, to be per se violations of the Act." Most regulations, however, are analyzed under the Supreme Court's "rule of reason," designed to address activities that, while not per se violations of the Act, are still considered to be illegal restraints of trade within a given market. ${ }^{54}$ The rule of reason essentially requires a court to take into account the circumstances of the alleged restraint and balance the anticompetitive and procompetitive effects of the alleged restraint. In addition, most lower courts have also added a "less-restrictive-alternatives" prong to their rule of reason analysis." Typically, after the plaintiff has shown significant anticompetitive effects and the defendant has rebutted them with a demonstration of significant procompetitive effects, the plaintiff must show that the same procompetitive effects could be achieved through less restrictive means."

51 See Standard Oil Co v United States, 221 US 1.59-60 (1911).

52 See ABA Section of Antitrust Law, Antitrust Law Developments 493 (ABA 4th ed 1997).

53 See United States v Socony-Vacuum Oil Co, 310 US 150,218 (1940):

[F]or over forty years this Court has consistently and without deviation adhered to the principle that price-fixing agreements are unlawful per se under the Sherman Act and that no showing of so-called competitive abuses or evils which those agreements were designed to eliminate or alleviate may be interposed as a defense.

54 Chicago Board of Trade, 246 US at 238.

55 See, for example, Continental TV v GTE Sylvania, 433 US 36, 49 (1977) ("Under this rule [of reason], the factfinder weighs all of the circumstances of a case in deciding whether a restrictive practice should be prohibited as imposing an unreasonable restraint on competition."). See generally Barry Wertheimer. Note. Rethinking the Rule of Reason: From Professional Engineers to NCAA. 1984 Duke L J 1297 (analyzing developments in the Court's interpretation of the rule of reason).

56 See, for example, United States v Brown University, 5 F3d 658, 679 (3d Cir 1993) (requiring evaluation of less restrictive alternatives to Ivy League financial aid agreement). See generally Renee Grewe, Antitrust Law and the Less Restrictive Alternatives Doctrine: A Case Study of Its Application in the Sports Context, 9 Sports Law J 227 (2002) (compiling less restrictive alternative cases, both in non-sports and sports cases).

57 Grewe, 9 Sports Law J at 232 (cited in note 56). The circuits vary in their application of the test, requiring either less restrictive alternatives, substantially less restrictive alternatives. or the least restrictive alternative. See id at 231. 
B. Applicability of Antitrust Laws to the NCAA

1. The NCAA is subject to antitrust scrutiny.

The NCAA was traditionally immune from antitrust scrutiny because of its nonprofit status. ${ }^{\text {sk }}$ However, courts have recognized that nonprofit entities can engage in commercial restraints on trade in violation of the Sherman Act." The Supreme Court first applied this principle to the NCAA two decades ago in NCAA v Board of Regents of the University of Oklahoma, striking down an NCAA regulation limiting the number of televised football games per season. The Court stated that "the economic significance of the NCAA's nonprofit character is questionable at best." ${ }^{, 61}$ Further, the Court noted that while "the NCAA's motives must be accorded a respectful presumption of validity, it is nevertheless well settled that good motives will not validate an otherwise anticompetitive practice." ${ }^{, 2}$

While Board of Regents clearly overturned the presumption that the NCAA is automatically exempt from antitrust scrutiny, few successful antitrust challenges to NCAA policies have been waged since. Courts often find NCAA regulations not to be antitrust violations because either: (1) they are not sufficiently commercial to be subject to antitrust scrutiny; ${ }^{63}$ or (2) their procompetitive effects trump their anticompetitive effects.

2. NCAA regulations with sufficient commercial undertones are subject to antitrust scrutiny.

Although the NCAA can be subject to antitrust scrutiny under Board of Regents, not all of its regulations are subject to scrutiny. Specifically, courts will subject commercial restraints by nonprofit entities to antitrust scrutiny, ${ }^{65}$ but will not apply antitrust laws to the limited

5x See Fleisher. Goff, and Tollison. $A$ Study in Cartel Behavior at 10 (cited in note 31) (discussing the lenient antitrust treatment historically afforded to the NCAA). Courts based this exemption on the fact that the NCAA was technically a nonprofit organization with an academic purpose. Thomas Scully. Note. NCAA v. Board of Regents of the University of Oklahoma: The NCAA's Television Plan Is Sacked by the Sherman Act, 34 Cath U L Rev 857,857 (1985).

59 See American Society of Mechanical Engineers, Inc v Hydrolevel Corp. 456 US 556, 576 (1982) (noting that it is "beyond debate" that nonprofit organizations can be held liable for antitrust violations); Goldfarb v Virginia State Bar. 421 US 773. 787-88 (1975) (holding a nonprofit professional organization liable for an antitrust violation).

60) 468 US 85 (1984).

61 Board of Regents, 468 US at $100 \mathrm{n}$ 22. The Court relied on the District Court's finding that "the NCAA and its member institutionș are in fact organized to maximize revenues." Id.

62 Id at $101 \mathrm{n} 23$.

63 See note 80 and accompanying text.

64 See note 81 and accompanying text.

65 See American Society of Mechanical Engineers. 456 US at 576 (examining the Mechanical Engineers Association code specifying safety requirement): Goldfarb, 421 US at 781-88 
class of nonprofit activities considered to be the "antithesis of commercial activity." Therefore, a court examining the transfer rules must first determine, as a threshold matter, whether they are sufficiently commercial to warrant antitrust scrutiny.

It is difficult, however, to delineate a "bright line" between commercial and non-commercial regulations." Courts look in each case to "the nature of the conduct in light of the totality of the surrounding circumstances." Ultimately, courts must determine whether the conduct in question is within the scope of the regulatory authority granted to the organization."

a) Commercial regulations. Twice, courts have found NCAA regulations sufficiently commercial to merit antitrust scrutiny. However, these courts have not set out a clear test for what constitutes a commercial restraint. In Board of Regents, the Supreme Court essentially assumed that the NCAA's restriction on the number of televised football games was a commercial restriction." More recently, the Tenth Circuit in Law $v N C A A^{\prime \prime}$ held that an NCAA-imposed salary cap on Division I entry-level basketball coaches was an unlawful restraint of trade. $^{27}$ As in Board of Regents, the court assumed that the regulation was commercially motivated."

These cases at least establish that economic restraints affecting entities other than student-athletes are sufficiently commercial to warrant antitrust analysis. Similar holdings abound in other nonprofit contexts. ${ }^{74}$ it is uncertain how much further courts would be willing to

(scrutinizing a County Bar Association's advisory fee schedule).

6h See Brown University, 5 F3d at 665-68 (holding an Ivy League financial aid policy sufficiently commercial to warrant antitrust scrutiny). See also Marjorie Webster Junior College, Inc v Middle States Association of Colleges and Secondary Schools, Inc, 432 F2d 650, 654 (DC Cir 1970) (exempting from antitrust scrutiny those activities that are clearly motivated by something other than commercial interests).

67 See Richard J. Hunter, Jr., Issues in Antitrust, the NCAA, and Sports Management, 10 Marq Sports L J 69, 80 (1999). Examples of regulations falling in a "gray area" between commercial and non-commercial might include some recruiting and financial aid rules.

68 Brown University, 5 F3d at 666.

69 See Peter C. Carstensen and Paul Olszowka, Antitrust Law, Student-Athletes and the NCAA: Limiting the Scope and Conduct of Private Economic Regulation, 1995 Wis L Rev 545, 576-77 (discussing the implementation of this standard in different cases).

70) Board of Regents, 468 US at 99 ("It is also undeniable that these practices share characteristics of restraints we have previously held unreasonable."). The Court's characterization of the television ban as commercial is further demonstrated by the dissent's objection: "[T]he Court errs in treating intercollegiate athletics under the NCAA's control as a purely commercial venture in which colleges and universities participate solely, or even primarily, in the pursuit of profits." Id at 121 (White dissenting).

7 I 134 F3d 1010 (10th Cir 1998).

72 Id at 1024 .

73 Id at 1021-24.

74 See, for example, American Society of Mechanical Engineers, 456 US at 576 (subjecting the Mechanical Engineers Association code specifying safety requirements to antitrust scrutiny); 
take this principle. The plaintiffs' success in Board of Regents and Law suggests that student-athletes could have increasing success in challenging NCAA regulations with similar economic motivations."

b) Academic or amateurism regulations. The Supreme Court in Board of Regents suggested that some regulations necessary to enhance competition in sports - and thus necessary to enhance public interest-should survive antitrust scrutiny. ${ }^{\text {16 }}$ The Court stated that "[i]n order to preserve the character and quality of the 'product' [of college athletics], athletes must not be paid, must be required to attend class, and the like. And the integrity of the 'product' cannot be preserved except by mutual agreement." Following this logic, several courts have upheld NCAA regulations governing academics and amateurism against antitrust challenges.

First, courts often exempt such regulations from antitrust scrutiny on the grounds that they are non-commercial. But courts have yet to develop a bright-line rule dictating which NCAA requirements are sufficiently motivated by academics and amateurism to be noncommercial. $^{7 \pi}$ This effort is further complicated by the fact that in the amateur sports context, the commercial motives behind a regulation can be masked easily. ${ }^{79}$ Nevertheless, several courts have concluded that NCAA regulations are not sufficiently commercial to be within the reach of the Sherman Act at all. Courts have used this rationale to reject antitrust challenges to NCAA eligibility rules. ${ }^{\mathrm{x}}$ Ultimately, the courts emphasized that the regulations furthered the NCAA's legitimate goals of amateurism and competitive balance, and not commercial objectives.

Goldfarb, 421 US at 781-88 (holding that a bar association's minimum-fee schedule for legal services falls within the ambit of antitrust law); Brown University, 5 F3d at 665-68 (holding an Ivy League financial aid policy sufficiently commercial to warrant antitrust scrutiny).

75 See Stephanie M. Greene, Regulating the NCAA: Making the Calls under the Sherman Antitrust Act and Title IX, $52 \mathrm{Me} \mathrm{L} \mathrm{Rev} \mathrm{81,} 95$ (2000) ("The coaches' successful challenge [in $L a w]$ should send a clear message to the NCAA that any regulations that have commercial overtones will not stand up to Sherman Antitrust analysis."). See also Hunter, 10 Marq Sports L J at 85 (cited in note 67) (arguing that Law might call into question NCAA limitations on the number and monetary amount of athletic scholarships).

76 Board of Regents, 468 US at 117.

77 Id at 102.

78 See Hunter, 10 Marq Sports L J at 80 (cited in note 67).

79 See Fleisher, Goff, and Tollison, $A$ Study in Cartel Behavior at 7 (cited in note 31). See also Chin, Comment, 26 Loyola $L$ Rev at 1218 (cited in note 16).

8) See Smith v NCAA, 139 F3d 180, 184-87 (3d Cir 1998), vacd on other grounds, 525 US 459 (1999) (finding a post-NCAA baccalaureate eligibility rule to lack a sufficient commercial nexus to warrant antitrust scrutiny); Gaines $v N C A A$, 746 F Supp 738, 745-46 (MD Tenn 1990) (finding NCAA amateurism rules not to be commercial regulations subject to antitrust laws). But see McCormack v NCAA, 845 F2d 1338, 1343-45 (5th Cir 1988) (refusing to determine whether the NCAA's eligibility requirements are commercial and thus subject to antitrust laws). 
Alternatively, courts have reached the same result by engaging in an antitrust analysis of regulations focused on education or amateurism, but ultimately finding no anticompetitive effects or finding sufficiently procompetitive effects to survive a rule of reason analysis. Thus, courts have taken two alternative paths to reaching the same result, effectively shielding from antitrust scrutiny NCAA regulations motivated primarily by the goals of furthering education or amateurism.

\section{Courts' Application of Antitrust Law to the Transfer Rules}

While two courts have entertained antitrust challenges to conference or NCAA transfer rules, neither court conclusively decided whether the transfer rules: (1) are sufficiently commercial to warrant antitrust scrutiny; or (2) would survive a rule of reason analysis. Rather, the courts appeared to purposefully avoid the larger antitrust issues, instead deciding the cases on alternative grounds.

First, twenty years ago in Weiss $v$ Eastern College Athletic Conference, ${ }^{\text {x }}$ the District Court for the Eastern District of Pennsylvania failed to substantively address the antitrust implications of the transfer rules. In Weiss, a former tennis player at Arizona State University challenged the NCAA and Eastern College Athletic Conference (ECAC) transfer rules after transferring to the University of Pennsylvania. The District Court declined to issue an injunction against the application of the transfer rules, noting that the plaintiff had offered only speculative evidence of irreparable harm. ${ }^{\text {* }}$ However, Weiss was decided before the Supreme Court's decision in Board of Regents, and the court in Weiss was unclear as to the applicability of the antitrust laws to athletic conferences. ${ }^{\text {sh }}$

More recently, in 2001, Tanaka v University of Southern California $^{\mathrm{k} 7}$ involved an antitrust challenge to the Pac-10 conference transfer

8I See Hairston v Pacific 10 Conference, 101 F3d 1315, 1318-19 (9th Cir 1996) (holding that a student-athlete failed to show any anticompetitive effects of sanction rules); $M$ cCormack, 845 F2d at 1343-45 (holding that eligibility requirements are procompetitive and reasonable). See also Banks v NCAA, 977 F2d 1081, 1085-94 (7th Cir 1992) (finding that a student-athlete challenging NCAA amateurism rules lacked standing and failed to allege an anticompetitive impact on a discernible market).

82563 F Supp 192 (ED Penn 1983).

83 Id at 192.

84 Id at 195 ("Plaintiff has not offered evidence which establishes that he will suffer irreparable harm if relief is not granted").

85 See 468 US at $100 \mathrm{n} 22$ (recognizing that "the economic significance of the NCAA's nonprofit character is questionable at best," and that the antitrust laws apply to the NCAA regardless of its status as a nonprofit entity).

8h Weiss, 563 F Supp at 196 n 11 (questioning whether the ECAC's regulations constituted commercial activity for the purposes of antitrust laws).

$87 \quad 252$ F3d 1059 (9th Cir 2001). 
rules, which required any student-athlete transferring from one Pac-10 institution to another to "fulfill a residence requirement of two full academic years ... and [which] charge[d] the student with two years of eligibility in all Pacific-10 sports." ${ }^{\text {,*x }}$ A soccer player at the University of Southern California challenged the rules after she was sanctioned for transferring to the University of California, Los Angeles. ${ }^{\mathrm{xy}}$

The Ninth Circuit in Tanaka declined to determine whether the Pac-10 transfer rules were sufficiently commercial to come within the purview of antitrust law." Assuming arguendo that antitrust law did apply, the court held that the transfer rule in question did not have an anticompetitive impact on the market defined by the student as women's soccer in Los Angeles." The court first concluded that there was no actual harm to this small market, especially in light of the fact that the student-athlete specifically alleged that the invocation of sanctions was an isolated action of retaliation, imposed only on her. ${ }^{y 2}$ Further, the court concluded there could be no harm to a national product market because the Pac-10 rules apply only to studentathletes transferring within the conference. ${ }^{\text {y.3 }}$ The court did not address the underlying issue of whether transfer rules affecting larger, highrevenue markets - such as NCAA men's football nationally-could have an anticompetitive impact.

\section{Analogy to Professional Regulations}

Courts have suggested that an analogy can be drawn between rules governing transfers of players in college athletics and similar regulations in professional athletics. For example, the Tanaka court noted that "restrictions on student-athlete transfers could be loosely analogized to the National Football League free agency restrictions," which were invalidated as antitrust violations in Mackey $v$ National Football League. ${ }^{95}$ In Mackey, the Eighth Circuit examined the National Football League's Rozelle Rule, requiring professional football

$8 \times$ Id at 1061 .

89 Id.

9) Id at 1062 ("For purposes of our analysis, we assume, without deciding, that the transfer rule is subject to federal antitrust laws.").

9] Id at 1065 ("By attempting to restrict the relevant market to a single athletic program in Los Angeles based solely on her own preferences, Tanaka has failed to identify a relevant market for antitrust purposes.").

92 Id at 1064 (noting that if the Pac-10 conference were identified as the relevant market, the plaintiff "would still be unable to allege that the transfer rule has had a significant anticompetitive effect on this 'market' given her assertion that she 'is the only transferring athlete who had the sanctions imposed on her'").

93 Id.

94 Id.

95543 F2d 606 (8th Cir 1976). 
teams acquiring free agent players to compensate the players' old teams. The court found the Rozelle Rule to be a substantial restriction on the market for players, as there would be "increased movement in interstate commerce of players from one club to another" without the Rule." The regulation ultimately failed the court's rule of reason analysis, as the court found the purported procompetitive interests of maintaining competitive balance, protecting clubs' investments, and building team cohesiveness to be insufficient. ${ }^{9 *}$ Other courts have struck down similar professional sports regulations deterring free player movement."

The NCAA would likely argue that decisions regarding professional sports are irrelevant to the NCAA because college athletics is not a product, much less a product comparable to professional sports. ${ }^{1 / 1}$ However, this argument is unconvincing. As previously discussed, college athletics has become a commercial cartel. ${ }^{101}$ Any distinction between college and professional sports has become increasingly blurred by the high levels of commercialization in collegiate sports. ${ }^{112}$ Therefore, a court should use professional sports opinions as persuasive authority in collegiate sports cases.

96 See id at $609 \mathrm{n} 1$ (outlining the Rozelle Rule and its requirements).

97 See id at 620 (finding that the Rozelle Rule reduced player salaries, discouraged negotiations with free agents, deterred players from becoming free agents, and decreased player bargaining power). See also Kapp v National Football League, 390 F Supp 73, 82 (ND Cal 1974) (finding the Rozelle Rule to be "so patently unreasonable that there is no genuine issue for trial"), affd on other grounds, 586 F2d 644 (9th Cir 1978).

98 Mackey, 543 F2d at 621-22 (affirming the district court's conclusion that, even if restrictions on player movement were necessary to maintain the NFL's competitive balance, the Rozelle Rule was "significantly more restrictive than necessary" and therefore failed a lessrestrictive-alternatives analysis).

99 See, for example, Jackson v National Football League, 802 F Supp 226, 235 (D Minn 1992) (granting a temporary restraining order barring the NFL from restricting player movement under its right of first refusal and compensation rules); Smith v Pro Football, Inc, 593 F2d 1173, 1187 (D DC 1978) (holding the 1968 version of the NFL draft to be an unreasonable restraint on trade under the rule of reason); Denver Rockets $v$ All-Pro Management, Inc, $325 \mathrm{~F}$ Supp 1049, 1066-67 (CD Cal 1971) (holding the NBA's "four-year college rule," which prohibited a student from entering professional basketball until four years after his class entered college, to be in violation of the Sherman Act).

$1(0)$ See, for example, Board of Regents, 468 US at 101-02 (emphasizing that the "academic tradition" in college football distinguishes it from, and makes it more popular than, comparable professional sports).

101 See Part I.

102 See Telander, Something Must Be Done, Sports Illustrated at 92 (cited in note 16) (discussing the extensive commercialization of "amateur" college sports). Distinctions between college athletics and professional athletics might be relevant when examining purely academic regulations, such as a requirement that a student be enrolled in school. Nevertheless, the distinction is likely nonexistent when examining anything but the most educationally motivated regulations. 


\section{The NCAA Transfer Rules Violate the Sherman ACT}

An antitrust challenge to the NCAA transfer rules would require a three-step analysis. First, the court must examine whether the transfer rules are sufficiently commercial to warrant antitrust analysis. Second, the court must define the relevant market and the agreement at issue. Third, the court must engage in a rule of reason analysis, balancing the procompetitive and anticompetitive effects of the transfer rules and examining whether there are any less restrictive alternatives to the transfer rules.

In this Part, I propose that the transfer rules are sufficiently commercial to warrant antitrust analysis. Then, I explain that the relevant market for antitrust analysis is the national market for studentathletes' services in a single sport. Finally, I argue that the transfer rules are a horizontal restraint on trade by the NCAA and its member schools, ultimately failing the rule of reason analysis on two grounds: (1) the anticompetitive effects of the transfer rules outweigh their procompetitive effects; and (2) even if the procompetitive effects of the transfer rules outweigh their anticompetitive effects, the transfer rules fail a less-restrictive-alternatives analysis. I thus conclude, that under both lines of reasoning, the NCAA transfer rules run afoul of antitrust laws.

\section{A. Transfer Rules Are Sufficiently Commercial}

As discussed in Part I, the NCAA acts as a commercial cartel, regulating a product, college athletics, in order to maximize profits for member schools. This cartel-like behavior would be per se illegal if engaged in by most commercial competitors; ${ }^{113}$ the NCAA has largely been able to avoid antitrust liability by purporting to further its legitimate non-commercial goals of promoting education and amateurism in college athletics.

Thus, the NCAA can easily mask commercial motives by purporting to regulate within its mandates to further education and amateurism. Indeed, organizations with legitimate mandates to solve externality problems can easily overcorrect the problems - eliminating socially beneficial competition - when the overcorrection is in the organization's best interest. ${ }^{1.4}$ For that reason, a broad antitrust exemption for "non-commercial" activity allows organizations too much leeway to mask self-interested restraints on competition as the simple manage-

103 See Wendy T. Kirby and T. Clark Weymouth, Antitrust and Amateur Sports: The Role of Noneconomic Values, 61 Ind L J 31, 31 (1985) (discussing the potential for federal courts to consider noneconomic factors in the rule of reason analysis).

104 See Peter James Kolovos, Note, Antitrust Law and Nonprofit Organizations: The Law School Accreditation Case, 71 NYU L Rev 689, 702 (1996). 
ment of externalities. ${ }^{105}$ Courts, therefore, should be skeptical of such overregulation and only exempt regulations that unquestionably further the NCAA's non-commercial regulatory mandates. ${ }^{1.6}$

1. Transfer rules are motivated by commercial rationales.

First, the NCAA transfer rules are sufficiently commercial to warrant antitrust scrutiny. The transfer rules are part of myriad NCAA regulations "restricting the freedom of athletes to make decisions which other students make in the regular course of their lives... designed not with the athlete's interest in mind, but with an eye on protecting the economic interests of the NCAA and its member schools."

The transfer rules are arguably meant to further schools' commercial interests in maintaining high-quality athletic programs at a low cost." First, coaches likely want to "lock in" their student-athletes. Once the team is locked in, coaches can focus their energy on winning games and raising revenues, rather than keeping players. In addition, the transfer rules ensure that teams get a return on their substantial investments in individual student-athletes. A "free market" system without the transfer rules would likely increase administrative costs to athletic programs and create disruption and inconvenience in recruiting."

In addition, the transfer rules disproportionately reflect the commercial interests of perennial NCAA "power" schools-those schools with consistent winning records and high revenues. Commentators argue that the NCAA "was established and has been operated over time in the interest of perennial college football powers." "Power schools have the most to gain from the transfer rules: They typically recruit the best student-athletes out of high school and therefore stand to benefit from "locking in" those student-athletes. Thus, the transfer rules likely reflect power schools' dual commercial interests

los See id.

106 By examining whether the NCAA has exceeded its mandate in each particular case, a court can strike down commercially motivated regulations without destroying the NCAA's ability to enact other necessary regulations. See Carstensen and Olszowka, 1995 Wis L Rev at 590 (cited in note 69).

107 Ray Yasser, A Comprehensive Blueprint for the Reform of Intercollegiate Athletics, 3 Marq Sports L J 123, 147-48 (1993).

108 See id at 147 (noting the cost-saving functions of NCAA transfer restrictions).

109 See id at 123, 147-48 (1993) (describing current transfer restrictions as cost-saving measures, and concluding that "the vast array of NCAA regulations restricting the freedom of athletes... are designed not with the athlete's interest in mind, but with an eye on protecting the economic interests of the NCAA and its member schools"). Several less restrictive alternatives to the transfer rules will be suggested in Part III.D.3.

110 Fleisher, Goff, and Tollison, $A$ Study in Cartel Behavior at 143 (cited in note 31 ). 
in maintaining their competitive advantage and increasing their revenues."

It is telling that the transfer rules apply in their most rigid form only to the "revenue sports," typically defined as men's basketball, football, and ice hockey. As mentioned above, student-athletes participating in non-revenue sports typically qualify for a one-time exception to the transfer rules. ${ }^{112}$ Possible academic and amateurism reasons for this distinction will be explored and ultimately discarded in later sections. Instead, commentators argue that the distinction results from the higher stakes in revenue sports, which ultimately enhance the athletic programs' power to lock in players: "Most coaches in minor sports want the same control over their athletes that the program heads in the revenue producers possess but, except for hockey coaches, they do not have enough clout within the NCAA to convince the association to extend its transfer rules to their sports."

2. Transfer rules are not motivated by academic goals.

The NCAA would likely argue that the transfer rules fall within the organization's mandate to further education and amateurism in college athletics. ${ }^{114}$ The transfer rules, however, do not further either mandate in practice. As one commentator put it: "The rationales proposed by the NCAA - that the [transfer] rules are designed to promote amateurism and to further educational goals - are both chimerical and disingenuous." demonstrated by several observations.

First, a student-athlete could get a high-quality education at a large number of colleges, and might receive a higher-quality education after transferring. ${ }^{116}$ Yet the transfer rules do not actually take academic motives for transferring into account. The only "academic" exception to the transfer rules allows a student-athlete to transfer without penalty if the student-athlete's academic program is discontinued at the original school. ${ }^{117}$ This limited exception does not take into account other academic reasons for which a student might transfer, such tions).

11 See id at 133-43 (discussing the influence of power schools in drafting NCAA regula-

112 See NCAA Operating Bylaws Art 14.5.5.1 (cited in note 1) (establishing a one-year eligibility penalty for transferring student-athletes); id Art 14.5.5.2.10 (providing student-athletes in non-revenue sports a possible one-time transfer exception).

$1: 3$ Sperber, College Sports Inc. at 240 (cited in note 11).

114 See Part I.C.

115 Yasser, 3 Marq Sports L J at 148 (cited in note 107).

116 See Chin, Comment, 26 Loyola L Rev at 1238 (cited in note 16) (recognizing that "most athletes can get an excellent education at one of several different universities," and that the transfer guidelines do not take this parity of educational excellence into account).

117 See NCAA Operating Bylaws Art 14.5.5.2.3 (cited in note 1). 
as a desire to change a major, a loss of scholarship assistance, or even a desire to acquire a higher-caliber education. ${ }^{118}$ Nor do the rules take into account the relative educational quality of the institutions involved, or include a limited waiver for clear improvements in educational quality. The rigidity of the transfer rules thus belies the argument that the NCAA is primarily concerned with academics. ${ }^{119}$

Second, it is unlikely that the rules are motivated by concern that student-athletes have ample time to adjust to a new academic environment, as the NCAA claims. ${ }^{121}$ Arguably, transfer students might need to play "catch-up" - their peers have already adjusted to the school, team, and community. These same restrictive rules, however, do not apply to student-athletes transferring from junior colleges to four-year institutions. ${ }^{121}$ Arguably, junior college transfer students need as much, if not more, time to adjust to the demands of a four-year college program. Further, a similar regulation barring freshman studentathletes from competition was abandoned decades ago. ${ }^{122}$ But that regulation was more defensible:

If a transferring "student-athlete" who has already adjusted to college life at one school requires a year to feel comfortable at a new institution, freshmen, often away from home and on their own for the first time in their lives, need even more time to adjust to college, especially to difficult academic work. ${ }^{123}$

Ultimately, the educational problems associated with geographic transitions cannot support the current transfer rules.

Third, it is unlikely that the rules are motivated by a concern that student-athletes contemplating transfers will be distracted from academics. Indeed, contemplating a transfer likely requires time searching out schools and contacting coaches. But this "distraction" is likely not more significant than other similar distractions facing student-

\footnotetext{
118 See Tanaka, 252 F3d at 1062-63 (discussing plaintiff's desire to transfer into a more rigorous academic program, and noting allegations of "sham" classes for star athletes at her prior institution).

1i9 In fact, the rules might harm a student academically, as the rules might deter studentathletes from transferring for purely academic reasons.

120 See McHale v Cornell University, 620 F Supp 67, 68 n 4 (ND NY 1985) (listing several NCAA rationales for the transfer rules, including a period of adjustment for new educational environments).

121 See NCAA Operating Bylaws Art 14.5.4 (cited in note 1) (listing exceptions to transfer rules for transfers from junior colleges to four-year colleges).

122 Sperber, College Sports Inc. at 241 (cited in note 11) ("Freshman eligibility in all NCAA sports began in 1972. Since then, the association has never wavered from this decision, although, on occasion, some college presidents and at least one major conference have tried to begin the repeal process."). The NCAA made freshmen eligible for economic reasons: Since the colleges were offering scholarships for freshmen, it was economically inefficient to bar them from playing. See Zimbalist, Unpaid Professionals at 21-22 (cited in note 7).

123 Sperber, College Sports Inc. at 241 (cited in note 11).
} 
athletes, from social opportunities to athletic responsibilities. Finally, other academic regulations, such as minimum grade point requirements for eligibility, go directly to making sure a student-athlete performs academically despite potential distractions. Thus, the transfer rules are not needed to further the educational goals of the NCAA.

3. Transfer rules are not motivated by amateurism goals.

The transfer rules are not intended to further the NCAA's goal of maintaining a competitive amateur athletic league. ${ }^{124}$ First, as a practical matter, the NCAA has already departed from its old ideals of amateurism. ${ }^{125}$ Simply put, a billion-dollar industry should not be able to shield itself from antitrust laws by hearkening back to its humble past. As one commentator has argued: "Courts should abandon anachronistic precedent based on unrealistic ideals of the 'amateur' nature of 'big-time' college athletics and develop a principled antitrust jurisprudence more consistent with the economic realities of college sports in the 21st century." ${ }^{126}$

The NCAA has argued in litigation that the transfer rules are needed to prevent student-athletes from transferring solely for athletic reasons, ${ }^{127}$ which might threaten the amateur nature of college athletics. But the mobility of student-athletes alone is not enough to threaten the amateur nature of college athletics. Furthermore, evaluated in the light of its purported justification of preventing transfers solely for athletic reasons, the rule is both overinclusive (it restricts almost all transfers between Division I schools regardless of motivation) and underinclusive (it exempts transfers involving non-Division I schools motivated solely for athletic reasons).

Similarly, the NCAA has argued that the rules are necessary to prevent the exploitation of student-athletes. ${ }^{128}$ Yet the restriction of student-athletes could be seen as an exploitative practice itself, as it limits the free movement of student-athletes within the market.

Finally, an oft-cited rationale for athletic regulations is the need to maintain competitive balance to preserve the unique product of amateur sports. ${ }^{129}$ At first glance, the transfer rules seem to promote evenly balanced, competitive teams, as the best student-athletes can-

124 See generally Green, $52 \mathrm{Me} \mathrm{L} \mathrm{Rev}$ at 81 (cited in note 75) (rejecting the argument that transfer rules promote athletic competition and maintain competitive balance).

125 See Part I.B.

126 Mitten, 11 Marq Sports L Rev at 7 (cited in note 33).

127 See McHale, $620 \mathrm{~F}$ Supp at $68 \mathrm{n} 4$ (setting out the NCAA's rationales for the transfer rules).

128 Id.

129 See, for example, Law, 134 F3d at 1023-24 (recognizing that "the NCAA must be able to ensure some competitive equity between member institutions in order to produce a marketable product"). 
not simply flock to the best teams. In practice, however, it is unlikely that the transfer rules promote a competitive balance. First, the best teams recruit the best student-athletes right out of high school. Moreover, teams would likely be more competitive in a free market system. Certainly some talented student-athletes in lower-ranked athletic programs would transfer to higher-ranked athletic programs. But a team can only utilize the talents of a limited number of players. So at the same time, some student-athletes in higher-ranked programs would likely transfer to lower-ranked athletic programs for more playing time and exposure. Thus, the transfer rules arguably do not protect the competitive, amateur nature of college athletics.

The NCAA is not regulating within its legitimate mandates to promote education and amateurism in college athletics. Simply put, the NCAA is a commercial cartel, organized to maximize profits. At best, the transfer rules reflect overregulation of the NCAA's legitimate mandates in order to increase revenue. More likely, however, the transfer rules are entirely commercial; the NCAA's legitimate mandates are merely cover stories used to mask commercial regulation. Either way, the transfer rules are sufficiently commercial to warrant antitrust scrutiny.

\section{B. The Transfer Rules Affect a Significant Market}

A market definition requires an inquiry into the relevant product, geographic, and field markets. For example, the Supreme Court in Board of Regents defined the relevant market as that for college football broadcasts nationally."

The relevant product market in considering the transfer rules is that for student-athletes' services. A similar product market definition was used by the Eighth Circuit in Mackey, ${ }^{132}$ and implicitly accepted in the college athletics context by the Ninth Circuit in Tanaka. ${ }^{133}$ The

130 Note that the NCAA's interest in maintaining a competitive balance in college athletics is complicated by the increasing number of student-athletes leaving college for professional athletics. See generally Glenn Dickey, Fix Up College Basketball: A Plan to Keep the Stars in School Longer, San Fran Chron B2 (Mar 7,1996) (recognizing that few talented college athletes actually graduate); Curt Brown, A Matter of Class; Juniors Might Dominate Draft, Underclassmen Coming Out in Droves, Minneapolis Star Trib 1C (Apr 22,1993) ("In the last three [NFL] drafts, more than one-quarter of the first-round picks (22 of 84 ) had turned pro with college eligibility left."). On one hand, this early exit of student-athletes might upset the competitive balance, giving the advantage to otherwise weaker teams who do not lose their best players to the pros and thus can build a team with the same players over a four-year period. But on the other hand, the early exit of the "best" student-athletes might result in more evenly balanced, competitive teams generally.

131 See Board of Regents, 468 US at 112.

132 See Mackey, 543 F2d at 616-18 (defining the relevant market as that for players' services).

133 See Tanaka, 252 F2d at 1063-64 (rejecting the narrowly defined product market of the "UCLA women's soccer program" on the grounds that athletic conferences "compete in the re- 
relevant geographic market is national, as student-athletes are recruited nationally and attend universities throughout the country." Finally, the relevant field market is that for a single sport, as studentathletes typically specialize in just one sport. ${ }^{1.55}$ Thus, the relevant market for an analysis of the transfer rules is that for student-athletes' services nationally in a given sport.

\section{Transfer Rules Are a Horizontal Restraint on Trade}

A court must next define and characterize the specific restraint on trade at issue. ${ }^{136}$ The NCAA is essentially a cartel of member schools, ${ }^{137}$ which collectively exercise market power over student athletics. The member schools can therefore impose regulations on student-athletes (the inputs) to lower the cost to the member schools of producing athletic contests (the outputs). ${ }^{136}$ In essence, the NCAA transfer rules are "simple monopsonistic practices," ${ }^{\text {,3. }}$ functioning as a horizontal agreement by member schools to restrict free studentathlete movement within the relevant market. ${ }^{190}$

\section{Transfer Rules Fail Rule of Reason Analysis}

As outlined above, rule of reason analysis requires a court to balance the anticompetitive and procompetitive effects of the NCAA transfer rules. ${ }^{141}$ Much of this analysis turns on how the court characterizes the effects of the rules. ${ }^{142}$ In this Part, I argue that the anticom-

cruiting of student-athletes and [ ] are interchangeable with each other for antitrust purposes"). See also Banks v NCAA, 977 F2d 1081, 1095 (7th Cir 1992) (Flaum dissenting) (rejecting the majority's assertion that there was no injury to a discernible market, and instead defining the product market as "the nationwide labor market for college football players") (emphasis added).

134 See Lee Goldman, Sports and Antitrust: Should College Athletes Be Paid to Play?, 65 Notre Dame L Rev 206, 228-29 (1990) (advocating a national market definition for players' services in college sports). While the Tanaka court rejected a national market definition in that case, it did so because the Pac-10 transfer rules in question only applied to interconference transfers and thus only applied to students transferring within a smaller geographic area. See $252 \mathrm{~F} 3 \mathrm{~d}$ at 1064. The NCAA transfer rules, on the other hand, apply to student-athletes nationally.

135 See Goldman, 65 Notre Dame L Rev at 229 (cited in note 134) (discussing athlete specialization).

136 See, for example, Board of Regents, 468 US at 98 (first establishing that the challenged NCAA practice constituted a "restraint of trade").

137 See Fleisher, Goss, and Tollison, A Study in Cartel Behavior at 7-16 (cited in note 31) (summarizing several factors suggesting that the NCAA acts as a cartel).

138 Id at 58 (discussing the NCAA's market-manipulation abilities).

139 Id.

140 For a discussion of likely cartel motivations, see Part III.A.1.

141 See Part II.A.

142 See, for example, Note, Sherman Act Invalidation of the NCAA Amateurism Rules, 105 Harv L Rev 1299, 1308 (1992) ("The Court's deference to the NCAA's description of college sports makes the product-promotion rationale circular-a defendant can call any of its activities procompetitive if it can argue that the activity in question is essential to the product which it defines."). 
petitive effects of the transfer rules greatly outweigh any procompetitive effects.

1. Transfer rules have significant anticompetitive effects.

The NCAA transfer rules have two significant anticompetitive effects: restricting the movement of players between schools, and removing some players who transfer from the market altogether.

The Eighth Circuit in Mackey found that professional football's Rozelle Rule deterred the free movement of players among football teams. ${ }^{143}$ The Rule deterred teams from negotiating with and signing free agent players, as a rational team would only negotiate with and sign a free agent player if (1) the team could reach an agreement with the player's former team or (2) obtaining the player was worth the cost of the Rozelle Rule penalty. ${ }^{14}$

Similarly, the NCAA transfer rules deter the free movement of student-athletes among schools. As one commentator put it: The "transfer rules are part of the NCAA's control over athletes and were written to accommodate program heads' fears about the free movement of their employees." ${ }^{145}$ Players are not free to play immediately after transferring, and thus cannot immediately exploit or market their talents. Similarly, teams are not free to recruit the best players from other colleges. Ultimately, the restrictions substantially affect the market by curbing the free flow of student-athletes from one school to another. ${ }^{146}$

In addition, the transfer rules arguably have the effect of taking student-athletes out of the market altogether. As mentioned above, under other NCAA regulations, all players must complete their four seasons of eligibility within a five-year window. ${ }^{147}$ A student who has played three seasons of college sports but has been affiliated with a school for four seasons (likely because of a redshirt year ${ }^{145}$ ) would have to use his last year of eligibility in the next year in order to meet the five-year deadline. The student-athlete would have to choose be-

143 See Mackey, 543 F2d at 620 (stating that there was substantial evidence in the record to support findings that the Rozelle Rule deterred athletes' free movement, hindered collective bargaining, and lowered salaries).

144 See id at 618.

145 Sperber, College Sports Inc. at 239 (cited in note 11).

146 See id (noting that many coaches openly admit that greater student movement would certainly occur in the absence of transfer restrictions).

147 NCAA Operating Bylaws Art 14.2.1 (cited in note 1) (establishing a firm five-year window for all athletic eligibility).

148 A "redshirted" player can practice with the team and receive an athletic scholarship, but does not play. See Rand E. Sacks, The Restricted Earnings Coach under Sherman Act Review, 4 Sports Law J 13, 30 n 138 (1997) (defining redshirt players, and discussing their treatment under NCAA eligibility rules). 
tween staying at his institution and participating in college athletics or transferring institutions and leaving the market of Division I athletics altogether. Alternatively, student-athletes might choose to leave Division I athletics for Division II or III athletics, in which the one-year transfer penalty does not apply. ${ }^{1.9}$ The exit of student-athletes from the market of Division I sports thus harms the market by artificially reducing the number of student-athletes in the market, ultimately reducing the overall value of the market.

The exit of student-athletes from the market of college athletics is especially problematic in the cases of highly talented student-athletes, who will play professionally after college. ${ }^{150}$ The transferring studentathlete faces particularly severe consequences from sitting out for a year. The student-athlete could possibly hurt his professional chances, since he would not be "scouted" by professional teams during that year. This problem would be amplified if the student-athlete were nearing the end of his five-year window of eligibility, and thus would not have any playing time remaining after the year of academic residence. If the student-athlete's reasons for transferring were compelling enough, he could rationally decide not to transfer, but instead to leave college (and the relevant product market) to try to play professionally.

\section{Transfer rules have few procompetitive effects.}

Next, an examination of the NCAA transfer rules shows that they have few or no procompetitive effects on the market for players' services. Any such procompetitive effects are insufficient to outweigh their anticompetitive effects. In performing this calculus, a court may not consider the general social value of a practice, unless this social value has a positive impact on competition in the market.

149 See generally Rana L. Cash, Reversing Field: Coaches See Impatience Growing as WouldBe Football Stars Switch Schools, Dallas Morning News 12B (May 28, 2002) (discussing transfer of a football player from Division I school to Division I-AA school); Phil Axelrod, The Right Moves: Transferring from Division I to Smaller Colleges Has Helped Some Players Become BigTime Hits, Pittsburgh Post-Gazette D2 (Jan 25, 1998) (discussing the transfer of college basketball players from Division I schools).

150 Of all NCAA student-athletes, an estimated 1.3 percent of men's basketball players will play professionally, 2.0 percent of football players will play professionally, and 4.1 percent of men's ice hockey players will play professionally. See NCAA, Estimated Probability of Competing in Athletics beyond the High School Interscholastic Level, online at http:/www.ncaa.org/ research/prob_of_competing/index.html (visited Aug 25, 2003).

151 See, for example, Board of Regents, 468 US at 101 n 23 (recognizing that it is "well settled that good motives will not validate an otherwise anticompetitive practice"); National Society of Professional Engineers v United States, 435 US 679, 695-96 (1978) (finding that social goals such as promoting safety and ethical behavior are not procompetitive effects unless they regulate or promote competition within the relevant market). 
The analysis of the procompetitive effects of the NCAA transfer rules could proceed in several ways. First, it might be argued that the transfer rules are necessary to promote the unique product of college athletics. In Board of Regents, the Supreme Court emphasized that the NCAA can take steps to "preserve the character and quality of the 'product" of college athletics. ${ }^{152}$ Citing this and similar language, lower courts have upheld regulations deemed necessary to make college athletics different from other products, namely professional sports. ${ }^{1.33}$ The NCAA transfer rules, however, are not necessary to promote the unique product of college athletics in the same way as academic requirements, amateurism requirements, and general "rules of the game." ${ }^{154}$ Therefore, the maintenance of college sports does not justify the transfer rules.

It might also be argued that the transfer rules are necessary to enhance public interest in college sports. The Supreme Court in Board of Regents said that "[i]t is reasonable to assume that most of the regulatory controls of the NCAA are justifiable means of fostering competition among amateur athletic teams and therefore procompetitive because they enhance public interest in intercollegiate athletics." as previously discussed, it is unlikely that the transfer rules foster a competitive balance in practice. ${ }^{156}$ Indeed, under the transfer rules the same dynasty teams dominate college sports year after year."

Furthermore, other courts have held that competitive balance alone is insufficient to justify restraints on trade. In Law, the Tenth Circuit rejected the argument that caps on entry-level coaching salaries were necessary to maintain competitiveness, emphasizing that the NCAA was unable to produce evidence that the regulation enhanced

152 Board of Regents, 468 US at 102.

153 See, for example, McCormack v NCAA, 845 F2d 1338, 1345 (5th Cir 1988) (stating that eligibility requirements are necessary to maintain the unique product of college football "in the face of commercializing pressures").

154 Indeed, without the transfer rules, student-athletes would still be students and amateurs, subject to the same NCAA regulations governing education and amateurism. Contrast, for example, Smith v NCAA, 139 F3d 180, 185 (3d Cir 1998) (noting that the NCAA eligibility rules "primarily seek to ensure fair competition in college athletics"). Similarly, the transfer rules can be contrasted from necessary "rules of the game"-for example, the number of players on the field at a given time. The product of college athletics would not exist without such organizational rules. Without the transfer rules, however, college sports competitions would exist in essentially the same form.

155468 US at 117.

156 See Part IIl.A.3.

157 Even assuming arguendo the transfer rules do promote competitive balance, it is not certain that a high level of competitive balance necessarily promotes public interest. Of course, some competitive balance is necessary to maintain college athletics-spectators likely would not watch games with entirely predictable outcomes. But at the other extreme, spectators might not want to watch more evenly matched, mediocre teams. Having some extremely successful teams may actually enhance the public interest in college athletics. 
competition. ${ }^{1.5 x}$ Moreover, in the professional context, the district court in Mackey held that the Rozelle Rule was not necessary to maintain competitive balance in professional football. ${ }^{\text {s.9 }}$ Both Law and Mackey suggest that there would be a high burden on the NCAA to show that the transfer rules in fact enhance competition in a relatively unrestrictive manner.

Finally, it might be argued that the transfer rules enhance college athletics by providing continuity in programs. Spectators can more or less expect to be able to follow any particular player during all of his four-year career. Thus, the ability to watch a team grow "organically" at a given school, rather than as a conglomerate of players from various schools, might arguably be procompetitive. Nonetheless, this purported procompetitive effect should be rejected on two grounds. First, the Eighth Circuit held in Mackey that an interest in continuity was not enough to justify the NFL's Rozelle Rule, especially in light of the high degree of player turnover resulting from "trades, retirements and new players entering the League." ${ }^{\prime \prime \prime}$ Such logic can easily be extended to the NCAA - while players are not traded, overall turnover is likely even greater because players have a maximum of only four years of college eligibility. Second, the continuity in college athletics might not have a practical procompetitive effect. Spectators may value watching the best possible team over watching the same players for a number of years.

3. There are less restrictive alternatives to the transfer rules.

Finally, many lower courts have added a less-restrictivealternatives prong to the rule of reason test. ${ }^{161}$ This test analyzes whether the same procompetitive effects could be achieved through less anticompetitive means. Thus, even if the procompetitive effects outweigh the anticompetitive effects, a practice would nonetheless be illegal if the same procompetitive effects can be achieved through less

158 Law, 134 F3d at 1023-24 (emphasizing the lack of evidence that NCAA salary restrictions were necessary to maintain a competitive market for college basketball coaching staff, either by reducing team debt levels or by eliminating coaching inequalities).

159 Mackey v National Football League, 407 F Supp 1000, 1008 (D Minn 1975). The Eighth Circuit in Mackey held that even if such a rule was necessary to maintain competitive balance, the specific regulation was significantly more restrictive than necessary, and therefore a violation of the Sherman Act. 543 F2d at 622. See also Smith v Pro Football, 593 F2d 1173, 1183-87 (D DC 1978) (rejecting the argument that the NFL draft is necessary to enhance competitive balance in the league).

160) Mackey, 543 F2d at 621. See also Smith, 593 F2d at 1183-87 (holding that the NFL draft is more restrictive than necessary to enhance competitive balance in the league).

161 See generally Grewe, 9 Sports Law J at 231-36 (cited in note 56) (discussing the adoption and application of the less-restrictive-alternatives rule in several circuit courts). 
restrictive means. ${ }^{1.2}$ Applying this test, the Eighth Circuit in Mackey determined that the NFL's Rozelle Rule was overly restrictive. ${ }^{163}$ For example, although much of the rationale for the Rozelle Rule emphasized the movement of the best players, the Rule applied to all players regardless of talent. ${ }^{1.4}$ Further, the Rozelle Rule was unlimited in duration and unaccompanied by procedural safeguards, such as avenues for player input."

Similarly, the NCAA transfer rules are likely overbroad under a less-restrictive-means test, as there are several less restrictive alternatives to the rules. ${ }^{1 / 6}$ The NCAA restricts the transfers of all Division I student-athletes, regardless of talent, reason, or circumstance. As an alternative, the NCAA could emphasize the academic growth of student-athletes by allowing them to transfer without athletic penalty when the transfer would be beneficial academically. In addition, the NCAA could liberalize its exceptions to the transfer rules to allow for more movement within the market while still maintaining any limited restraints necessary to sustain college athletics. The NCAA could thus extend its one-time exception to revenue sports, allow for petition for waiver of the transfer rule, or add more exceptions to the transfer rules (such as an exception allowing a transfer without penalty if the coach who recruited a player leaves). The existence of these viable, easily implemented, and less restrictive alternatives should prove fatal to the NCAA's current transfer rules in any antitrust challenge.

\section{E. Policy Considerations Support This Result}

The conclusion that the NCAA transfer rules do not withstand antitrust scrutiny is supported by a number of general policy considerations. Simply put, the transfer rules are inconsistent with the organization's purported interest in the welfare of student-athletes. ${ }^{167}$

First, the rules harm the student-athletes whose professional careers may depend on their college eligibility. Courts have recognized, for example, that a student-athlete's professional basketball opportunities are related to his ability to play college basketball during his

162 See Mackey, 543 F2d at 621 (discussing the possibility that a practice could be illegal if less restrictive means could be found to implement it instead).

163 Id at 622 (suggesting that even if the Rozelle Rule's procompetitive benefits outweighed its anticompetitive effects, it would fail rule of reason analysis as overly restrictive).

164 ld.

$165 \mathrm{Id}$.

It6 Courts have applied this standard in various ways. For a discussion of the different approaches, see generally Grewe, 9 Sports Law J 227 (cited in note 56).

167 See Eroyles, 46 Ala L Rev at 532 (cited in note 4) (arguing that NCAA eligibility rules "are hard to reconcile with the organization's purported concern with the welfare of the studentathlete"). 
senior year. ${ }^{168}$ Additionally, the transfer rules might also have negative effects on mediocre or sub-par athletes wanting to transfer schools for any number of reasons. A player might wish to transfer because of a loss of a scholarship, as under NCAA rules scholarships can only be year-long and must be renewed by schools annually. ${ }^{169}$ Along the same lines, a player might wish to transfer if the coach who recruited him chooses to leave the school. While student-athletes are bound by stringent transfer rules, coaches can and do change schools at will."

Finally, and perhaps most troubling, the transfer rules harm student-athletes who want to transfer for reasons not related to athletics. The rules do not have sufficient exceptions for students who want to transfer for academic, family, or other reasons. The glaring inadequacies of the current transfer rules, and their complete lack of convincing justifications, reveal the true nature of the NCAA's present policies: a naked restraint on trade involving commercially valuable commodities.

\section{CONCLUSION}

Today's NCAA is a far cry from the organization's humble beginnings and rhetorical focus on standards of academics and amateurism. As the NCAA becomes increasingly commercialized, its rules and regulations should come under the same scrutiny as those of other commercial organizations. The NCAA transfer rules are anticompetitive commercial restraints without significant procompetitive benefits. Further, the transfer rules' minimal procompetitive benefits could be accomplished by less restrictive means. Given these effects, the current transfer rules implement a plainly illegal restraint on trade in violation of the Sherman Act.

168 See, for example, Hall v University of Minnesota, 530 F Supp 104, 106 (D Minn 1982) (stating that a player's NBA draft status was directly related to his ability to play college basketball during his senior year).

169 See NCAA 2002-03 Transfer Guide § VI (cited in note 38) (describing NCAA scholarship renewal policies).

170 For a recent example, see Ian O'Connor, Inequity of Antique Transfer Rule Hurts Only the Athletes, USA Today 2C (Apr 22, 2003); Carol Slezak, Left at the Altar, Chi Sun-Times 102 (Apr 20, 2003). 


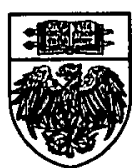

